\title{
Public Sector Engagements and Value for Money Audit in Nigeria
}

\author{
Sunday Ajao OWOLABI ${ }^{\mathrm{a}}$; Olubunmi Adewole OGUNODE ${ }^{\mathrm{b}}$ \\ awolabis@babcock.edu.ng \\ badexybum@yahoo.com
}

\author{
${ }^{\mathrm{a}, \mathrm{b}}$ Department of Accounting, Faculty of Management Sciences, Babcock University, Ogun State, \\ Nigeria.
}

\begin{abstract}
The desire and demand for value for money audit (VFM) in the public sector is significant because the confidence of the populace is gradually fading away due to inability of public servants at all levels to ensure transparency and accountability in public spending. Some prior studies have ascribed this to a lack of patriotism, and sheer display of incompetence and systemic inaptitude, others attributed this to weak control measures and ineffective value for audit, resulting to misappropriation, fraud, and stealing of public funds. Consequently, this study examined public sector engagements, from the perspective of value for money audit. The research approach adopted for the study was content analysis. The study revealed that if properly carried out, value for money audit has the capacity to enhance reduction in costs of governance, misappropriation and theft of public fund, assist government in redirecting scarce public resources to priority areas and restore public confidence in the management of national economies.Public sector engagements and establishments are advised to instill the culture of regular value for money audit in all public sector institutions to ensure protection and proper utilization of public fund.
\end{abstract}

Keywords: Accountability, Cost of governance, Management responsibility, Public sector, Value for money audit.

\subsection{Introduction}

Broadly speaking, any nation's economy is made up of the public sector and the private sector. While the private sector often lends itself to the principles of capitalism and profit maximization, the public sector is primarily focused on the delivery of social services to the populace at minimal costs. Funding for these social services often comes by way of taxes and levies imposed by governments on its citizens and as part of the social contract, the revenues generated is expected to be judiciously deployed to cater for the citizen's social needs. Ensuring that governments' meets up with this social contract provided the platform the development of what is now known as value for money audits.

According to Flesher and Zarzeski (2002), value-for-money auditing has had a rich and diverse history across several geographical boundaries. Multiple influential establishments like the General Accounting Office (Canada), American Institute of Management, the International Institute of Auditors (IIA) and the Canadian Comprehensive Auditing Foundation have played pivotal roles in the development of the concept. This view is also echoed in the works of Nirmala Van Peursem and Lowe (2006). According to Okwoli (2004), Nigeria joined the League of Nations adopting value for money audit following the Federal Government of Nigeria's Ayida's1995 report on the Civil Service Reforms. One of the recommendations was that the task of carrying out value for money audit be added to the schedule of responsibilities of the Auditor General. Thus, he is expected to have a functional team of auditors to carry out this responsibility at the local, state and federal levels. However, the functionality of this and the extent of effectiveness is still a matter that is subject to debate today. 


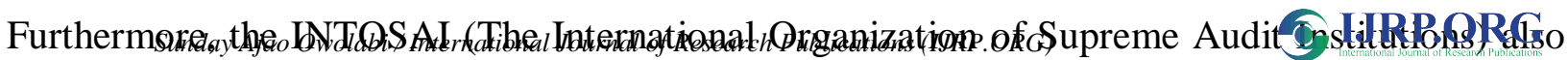
inferred that value for money auditing also known as performance auditing was introduced ing $_{3}$ the USA, Sweden and other Nordic countries, Great Britain and Canada in the late 1960s in response to the strident calls by various stakeholders for improved transparency in government spending (INTOSAI 1992).

The principles and practice of value for money auditing has evolved over time with mixed results in terms of impact in different geographical locations.

\subsection{Statement of the Problem}

The increasing rate of systemic rot in public spending due to lack of transparent and accountability in the public sector seemed unabated, and controlling these anomalies is quite challenging and multifaceted. There has been reckless spending and awkward rate of misappropriation and serial mismanagement in the government circle and in all levels of government globally, these are quite disturbing and worst hit is Nigeria. These unbridled spending that is not represented by actual feasible value on the ground has contributed in no small measure to Nigeria achieving the notorious title of the new poverty capital of the world. According to data released by the World Poverty Clock, Nigeria achieved this notorious title in June 2018 with over $86.9 \mathrm{~m}$ of the population living in extreme poverty. Unfortunately, recent statistics from the same globally acclaimed institution suggest a worsening of situation rather than an improvement (now 105m representing over $51 \%$ of the population as at September 2020). Furthermore, the rapid rise in population exacerbated by the huge infrastructural deficit relative to its peers in the developing world has made it all the more necessary to ensure optimal value is obtained per unit of income generated is achieved in Nigeria.

Persistent failures of government in addressing this deficit has unfortunately provided fertile grounds for widespread intra-community conflicts, destruction of lives and properties as well as the breeding of an army of restive youths (Idada and Ihunmwuangbo 2012). Thus, the dipping of public funds and inadequate optimal utilization of state revenue income by those saddled with the management of government resources have become major sources of concern and this parlous state has been traced to inadequate value for money audit and ineffective internal control in most public parastatals, ministries and government agencies (Nkwagu \& Nwangbebu, 2019). Adequate and effective periodic value for audit in all public establishments has the tendency to act as a control measure and reduce the appetite and propensity to misappropriation of public fund. It is based on this premise that this study was carried out so as to discuss these major concerns and how the deployment of effective value for money audit as part and parcel of a public sector audit engagement can be used to address them.

\section{Literature Review}

\subsubsection{Public Sector Engagements}

The steady upsurge in democratic governance around the world as opposed to dictatorships or absolute monarchies has given rise to greater interface between the governed and those who hold the reins of governance. These interfaces usually take the form of public sector engagements. Public engagement is a way of earning public trust and confidence and is multi-dimensional (Burchell 2015). According to Tan (2012), public engagements are a direct offshoot of participatory democracy and involve the exercise of decision making powers by knowledgeable experts for the greater good of the people. By virtue of the impact of such decision making powers exercised, accountability is usually demanded by the citizenry hence the recourse to the use of experts such as auditors (Bloomfield et al 2001). These experts are expected to inform and provide guidance where necessary on policy decisions and actions of public sector players. These actions include proper appropriation and disbursement of public funds. 


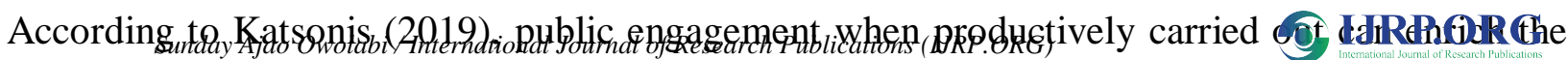
task of policy-making and the quality of decisions made. This is in alignment with the yint $^{2}$ expressed by OECD (2009) who asserted that it is a vital key to ensuring operative governance. The engagement methodology emphasizes credibility and responsibility as well as enhancing the capacity of the citizenry to demand for optimal service delivery. It is under this platform that value for money audit emerges as a fundamental public sector engagement tool.

\subsubsection{Value for Money Audits}

Audit involves independent review of the financial records of an entity. The demand for such independent review stems from the desire to ensure proper stewardship and accountability of public funds. The need for quality audit is further underscored by the fact that low quality audits has the potential of misleading investors and consequently misallocation of scarce economic resources (Salehi 2010). Audit is carried out by an appointed, professional accountant charged with the responsibility of providing an expert judgment, documentation, substantiation or counsel on a set of prepared financial statements (Ogoun and Odogu 2020). Auditing as a profession has long been looked at as a practical and learned endeavor rather than a theoretical based profession. Thus, early practitioners saw it simply as one involving the use of methods, techniques, practices and procedures for carrying out reviews and inspections of financial records. This is also in alignment with the views of Owolabi et al (2016) which stressed the changing roles of auditing from a past saturated with fraud detection responsibility to a future to be dominated by the use of sophisticated audit software.

According to Tonade \& Adesanawo (2017), VFM audit is a terminology used for the evaluation of the extent to which optimal use is made of an organization's resources. It is a term more commonly used in the public sector than the private sector. Public sector in this case, according to the International Institute of Auditors(IIA 2011) refers to governments and all publicly controlled or publicly funded agencies, enterprises, and other entities that deliver public programs, goods, or services. Thus, they include government parastatals, ministries, departments and agencies (MDAs), public utilities boards or corporations and local authorities.

Mhilu (2002) views value for money audit as an activity carried out by a group of qualified auditors involving assessment of costs minimization per each unit of output generated in order to foster productive future projections. The operative word for him was cost which he viewed as been central to the subject of entities securing value. In the opinion of Oshisami (2004), VFM defines whether the organization is obtaining, handling or properly exploiting its assets (such as human personnel, structures and resources) in an economic and efficient manner. In Okwoli (2004)'s view, value for money is a methodical appraisal of the approaches used to carry out government ventures, plans and schemes. He therefore posited that value for money entails an assessment of the extent to which government's stated plans and projects have been executed within the bands of accountability.

For the purpose of this study, VFM audit will be regarded as a mechanism for assessing how governments' uses finance in its custody to judiciously implement programs, policies and projects for the betterment of the citizenry at a cost that is economical and efficient. The level of interests and importance attached by various stakeholders to value for money audits have differed from one jurisdiction to another. For example, Munian (2005), observed that in a survey involving 18 countries out of which 14 were mainly European Union countries, the level of interest was very high. He found that there was a direct correlation between interest level and the performance of the institutions producing the value for money audit reports. The fact that it is commonly associated with the public sector does not make it lose the central strength of audit 


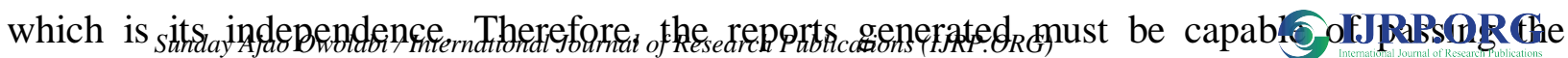
scrutiny of knowledgeable stakeholders.

Value for money is now a benchmark against which the performance of local authorities is measured (McSweeney 1990). Therefore, each local authority is expected to be able to properly account for every purchase or every money spent while ensuring that the public derive the expected utility from the social service being rendered. They may be performed either as standalone assignments or as part of the internal audit function.

\subsubsection{Elements of Value For Money Audit}

There are three (3) main elements involved in value for money audit and these are briefly described below:

Economy: This shows the relationship that subsists between costs and input resources (Nwangbebu et al 2019). It simply refers to the acquisition of inputs of a given standard and quality at the lowest possible costs. This therefore implies spending less per time. Doing this will demand the prudent use of resources in such a way that time, efforts and money is saved.

Efficiency: To be deemed efficient will imply accomplishing certain milestones (i.e. maximum output or minimum input) with less time, effort or expense.It is thus a measure of productivity (Nwangbebu et al 2019). In order words, it implies spending well per time. Mathematically, it is given as output or value received divided by inputs or resources deployed.

Effectiveness:This is the extent to which organizational activities achieves the intended results or objectives which can be quantitative or quality in nature.Effectiveness entails ensuring that organizational outputs are as closely aligned as possible to its stated objectives.In order words, it implies spending wisely per time.

\subsubsection{Aims of Value For Money Audit}

The overriding objective of value for money audit is to provide needed assurance that public funds have been judiciously, economically and efficiently used for the original purpose intended as set out in a government's program, policy or budget. Thus, if properly administered, the outcome of a value for money audit should naturally serve as input into an ensuing budget cycle.

According to the Northern Ireland Audit Office, (NIAO 2015), the primary objectives of value for money (VFM) audit are to:

i. "Make available to the Assembly independent information and advice about how economically, efficiently and effectively departments, agencies and other central government public bodies have used their resources;

ii. Inspire audited bodies to increase their performance in achieving value for money and implementing policy; and

iii. Recognize good practice and recommend ways in which public services could be improved."

The above views therefore establish the expected independent nature of a typical value for money audit. Daujotaite \& Macerinskeience (2008) in their contribution to the discourse affirmed that the focus of value for audit is to evaluate the efficiency of utilization of human, financial and other resources inclusive of information systems. This is done with regards to the relevant statutes and or legislations guiding the operations of the public sector entity. 


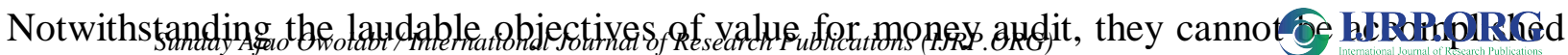
if the management or administrators in the public sector do not provide the auditor ${ }^{2}$ witith ${ }^{2} 6$ the needed environment to carry out the assignment.

\subsubsection{Value for Money Audit Process.}

Value for audit money process can broadly be categorized into three phases: the pre-engagement audit phase, engagement phase and the post audit phase respectively. The pre-engagement phase involves the range of activities carried out before the commencement of the value for money audit engagement service. These typically include establishment of management responsibilities' and terms of reference for the service, audit planning and staffing issues. Special care and attention must be paid to this phase as it sets the tone for the failure or otherwise of the entire value for money audit process.

The engagement phase refers to the range of activities carried out in the course of the actual value for money audit engagement service. These will typically include timing considerations, controlling, supervision and documentation of the audit findings. According to the Public Company Accounting Oversight Board (PCAOB 2010), although documentation alone does not guarantee audit quality, the process of preparing sufficient and appropriate documentation contributes to the overall quality of the value for money audit and is thus very essential.

The post engagement phase refers to the range of activities carried out upon the conclusion of the value for money audit engagement. This involves review and reporting. The review is done to ensure that reliable, relevant and sufficient audit evidence has been obtained that will validate the outcome of the audit engagement.

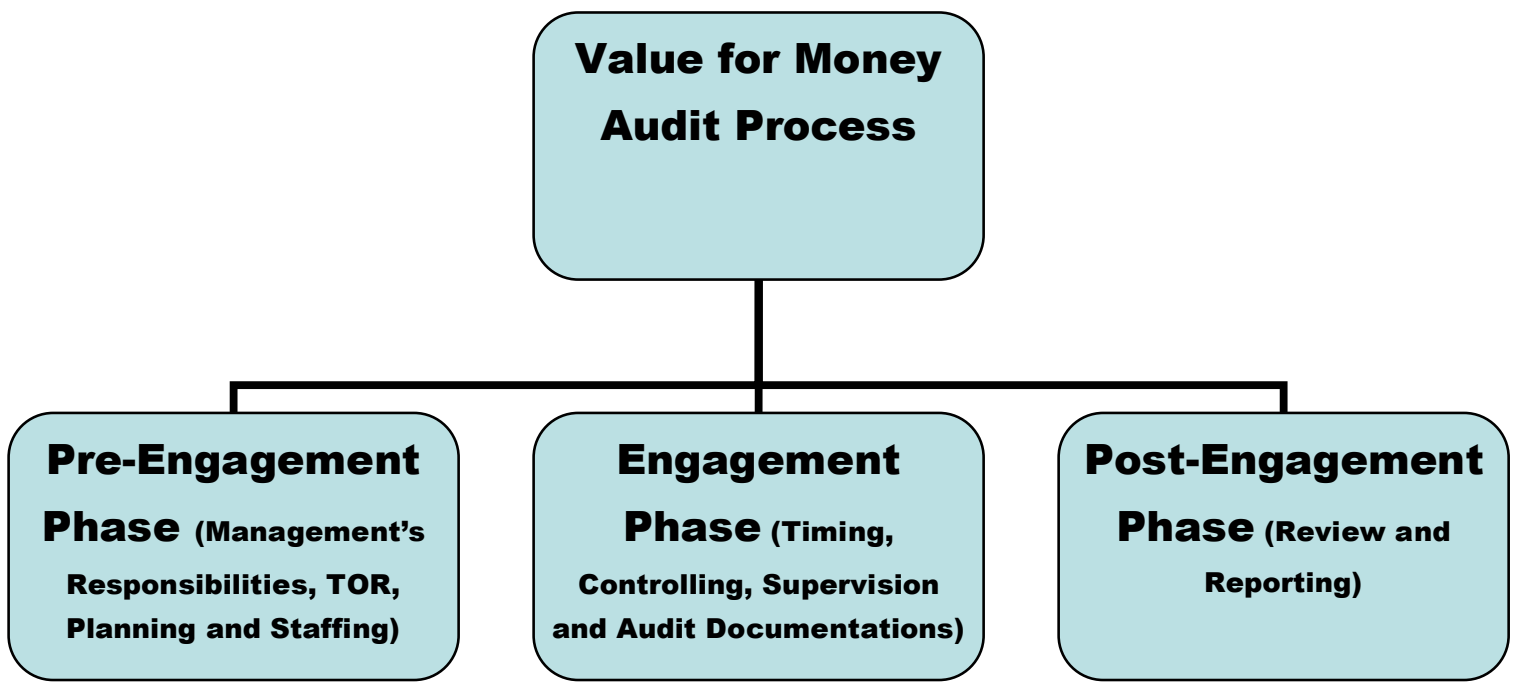

Fig 1: Value for Money Audit Process Diagram

\subsubsection{Problems of Value for Money Audit - The Nigerian Perspective}

Value for money audit in Nigeria has suffered from a number of key limitations, some of which are discussed below:

i. Skills Requirements: The success or otherwise of a value for money audit depends largely on the level of skills, knowledge and expertise of the individuals assigned to the task. Where this is deficient, the likely resultant effect will be an undependable report. For example, a review by Oshisami (2004) showed that there is a serious dearth of professional skills and 


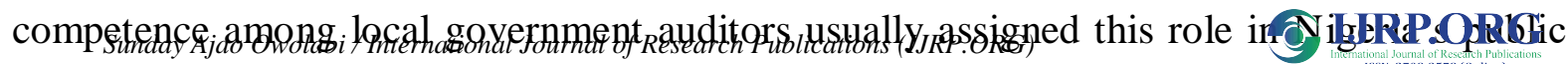
sector.

ii. Difficulty in Measuring Outputs and Efficiency: Outputs and by extension efficiency as it relates to the public sector is quite fluid and difficult to quantify as a lot depends on the judgment exercised by public sector players. Furthermore, objectively quantifying maximization of public welfare as an output component is difficult to measure.

iii. Loopholes in Legislative Frameworks: According to Udeh et al(2016), at the moment, no sanction powers has been given to the office of the Auditor General of the Federation to compel MDAs to observe and comply with instructions issued for the purpose of instituting value for money audits in the respective offices. This is a major gap as operators generally will not subject their operations to audits except if compelled to do so.

iv. Unsatisfactory Performance of the Public Accounts Committee: The major responsibility of the Public Accounts Committee is to ensure transparency and accountability as they are traditionally the public spending watchdog. However, a cursory look at the myriads of reported cases of financial irregularities in several MDAs indicate that their performance so far is less than desirable.

v. Accounting Basis: Public sector finance is rendered using the cash accounting basis rather than the accrual accounting basis associated with financial statement audits. This is capable of misrepresenting the true financial state of the entity (Eze et al 2015).

vi. Absence of Sound Internal Control Systems: Most public sector entities have defective internal control systems that do not allow auditors to place reliance on the integrity of the existing system. This therefore inhibits the ability of auditors assigned to the public sector engagements from producing qualitative work.

vii. Lack of Political Will: To succeed, value for money audits requires the express and implicit approvals of political actors who are often the key decision makers for respective MDAs. Thus, where this is not in place, artificial barriers may be put in place that will frustrate the success of the audit engagement. In addition, where the exercise has been done, political will is required to see through the implementations of the recommendations made in the reports.

\subsection{Theoretical Framework}

This study is underpinned by a number of theories which are briefly discussed in this section.

\subsubsection{Stakeholders Theory}

The stakeholder theory is a theory advocated by Freeman in 1984 . He defined a stakeholder as any person(s) that has influence or can be influenced by the business of the organization in the quest of achieving its purpose (Freeman, 1984). The stakeholder theory is essentially a theory focused on how a business entity operates at its best especially taking into cognizance its interrelationships with its operating environment. This operating environment consists of parties that affect or is affected by the core decisions taken by the business entity. These parties include individuals that matter such as customers, lenders, creditors, employees and external communities. The continued existence of any organization depends on the support and the endorsement provided by these players. The theory is supported by several scholars such as (Agle, Mitchell, and Sonnenfield, 1999; Santos and Brito, 2012). These scholars reiterated that the theory offers a social perspective to the objectives of the firm and, to an extent, conflicts with the economic view of value maximization in such a way that the needs of the other users are met. However, authors like Blattberg (2013) has criticized stakeholder theory for assuming that the interests of the various stakeholders can be, at best, compromised or balanced against each other.

Notwithstanding the above criticism, in the view of the researchers, the stakeholder theory is considered germane to the study under review as it recognizes the multiplicity of parties that can 


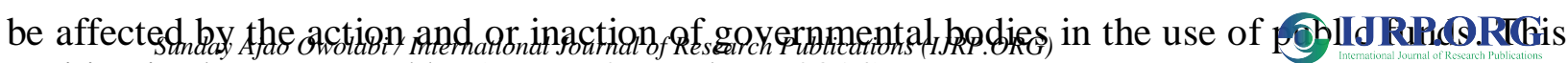
position is also supported by (Peters \&Bagshaw, 2014).

\subsubsection{Public Interest Theory}

The origin of public interest theory is traceable to the works of Albert Pigou (1932). The theory assumes that government exists to benefit society as a whole rather than vested interests as is common place in the private sector. Thus, government adopts a welfarist approach in tending to the needs of society. This is because private sector led markets are assumed to provide veritable platforms for the development of monopolies and all its associated problems to the detriment of public good (Shleifer 2005). Thus, governments exists to check these monopolistic tendencies by engaging in activities such as price control, setting of minimum wage parameters, encouragement of workers unions and imposition of safety standards in the work place. The theory has been largely embraced by most developing economies to combat the wave of capitalism sweeping across the world. It has also influenced the growth of nationalized assets and government owned public entities. This theory is supported by the works of Hantke-Domas (2003) and Hertog (2010), who view it as a tool to be used to address the problems of efficient allocation of resources in the society. The theory has however, been criticized by believers in the private interest theory who assert that in real life, inherent in society are private individuals strong enough to form groups to champion their respective self interests to the disadvantage of the larger group(Smyth 2010). Furthermore, government led initiatives' such as price control are often subject to abuse and reflect high degree of incompetence and greed on the part of public sector regulators and is thus not a realistic option for positively influencing the direction of the market. Additionally, it has been argued that the impact and existence of private competition will whittle down the influence or probabilities of monopolies holding sway for an indeterminable time. These various oppositions are however not sustained by the researchers who are of the opinion that the welfarist obligation that governments hold to the larger society should at all times guide their activities. The auditor is thus needed to ensure government can be held accountable to this sacrosanct obligation that it holds to the society.

\subsubsection{Theory of Inspired Confidence}

The theory was propounded by Professor Limperg (1932). He affirmed that the demand for audit services is the direct consequence of the participation of outside stakeholders who are third parties to the entity. These third parties (outside stakeholders) therefore demand accountability in return for their contribution to the company (Ittonen 2010). In the public sector, this contribution comes by way of fines, levies and taxes and such contributors (tax payers) demand accountability in return for faithfully living up to their civic responsibilities. The theory assumes that given that information provided by management of an entity may be prejudiced, there is the need for an independent party to provide needed assurance on the reliability or otherwise of the information. According to Duits (2012), the theory simultaneously connects the social needs for reliable financial statements with the technical possibilities of auditing to meet these needs.

The theory also closely approximates the theory of rational expectations which holds that economic agents will usually benchmark their decisions on the strength of the quality of information available to them as well as the established past performance trends (Grossman 1981). The economic agents in this case believe that past outcomes will more than likely influence future outcomes. Thus, where public sector players have been found to demonstrate unbridled corruption in the past, the same or similar outcomes will be expected in the near future. There is therefore the need for an independent party to break this vicious chain by providing credible and reliable information that can be used to restore public confidence. Limperg's views have been supported by David Flint (1988) and Mautz \& Sharaf (1961) who stressed that 


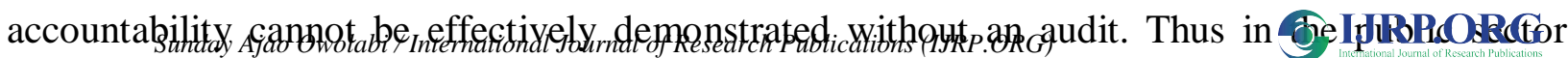
space, for tax payers to secure the needed assurance of the judicious use of tax revenue, the need for an audit such as value for money audit which is the subject of this discourse.

\subsubsection{Policeman Theory}

The theory was propounded by Prof Limperg in the late 1920s (Hayes et al 1999). The theory asserts that the primary function of the Auditor is two-folds: the prevention and detection of frauds on the one hand and the checking for arithmetic accuracy of financial reports on the other hand. Accordingly, the auditor is responsible for searching, discovering and preventing any fraudulent activity. The auditor in this case is consequently seen as a watchdog rather than a bloodhound. Scholars such as Sombert (1953) and Salehi (2010) have supported the theory. The theory however began to lose much relevance in the 1940s following the development of other audit demand backed theories and its failure to speak to the need to establish the truth and fairness of a set of financial statements.. However, the occurrence of the Enron, WorldCom and associated scandals, resulted in an increasing clamor for auditors to assume this role again so as to provide the needed assurance for users of financial statements (Olaoye et al 2019, Salehi 2010).

\subsubsection{Theory of Lending Credibility}

The theory represents a shift of emphasis from the perceived role of the auditor as a policeman to that of a verifier of the truth and fairness of the financial statements. The theory affirms that the principal function of the auditor is to add credibility to the financial statements or reports prepared by the management of an entity (Shaw 1980). In this theory, the auditors' major service selling point therefore is credibility (Okpala 2015).Thus, users of financial statements are able to make better informed decisions on the strength of financial statements that have been reviewed or audited by knowledgeable, independent third parties serving as auditors. The theory works on the assumption of the existence of conflict of interest which generates expectation gap between the roles performed by management and what users of financial information desire. The need to bridge this gap is further underscored in this work as societal expectations of probity and accountability weighs heavily on the government on one hand and the auditor on the other hand.

\subsection{Empirical Review}

There have been a number of empirical studies on the subject of value for money auditing especially as it relates to the public sector and public accountability. Some of these alongside their findings are briefly discussed hereunder.

Tanko Samuel and Dabo (2010) carried out an empirical examination of VFM audit using some designated local councils in Nigeria as case study. The researchers distributed closed ended questionnaires for its data collection while the chi-square and tables were used for the analysis of data collected. The study found that local government council administrators were not following due process especially in the area of contract awards with the resultant negative effect on value for money in the localities. To reverse this trend, the study recommended that due process must be adopted in contracts award and management.

Chew,Suhaiza and Fatima. (2016) carried out an evaluation of the sensitivity of public sector auditors to performance audits conducted in Malaysia. The research work adopted the use of a postal questionnaire which was administered on purposively selected target audience. The findings showed that lack of cooperation and cooperation with auditors was the topmost constraint inhibiting success of VFM audit. The study concluded that VFM audit enhances public 


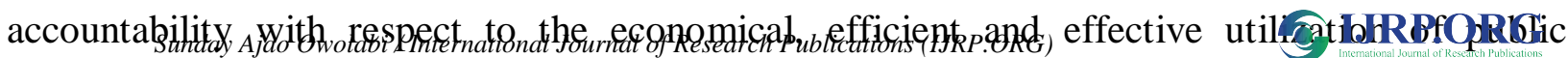
resources.

Changalima (2016) investigated the causative elements of VFM in the procurement of works in the public sector of Tanzania. The study employed a descriptive approach and found that procurement planning and ICT usage in the procurement processes were the major determinants of value for money in the procurement processes in the selected ministries'. The study then recommended that public entities should ensure that procurement planning and e-procurement are employed to enhance successful improvement of value for money.

Parker (1986) studied the body of work relating to performance auditing conducted on the Australian Accounting Research Foundation. The study showed that while expressions such as value for money, operations and operational audit, performance audit and management audit have been variously employed in theory and practice, evidence from the research revealed that there is a sharing of common basic definition founded upon the concept of economy, efficiency and effectiveness. The researcher therefore argued that a value for money audit 'was any audit that attempts to evaluate organizational performance based upon the three criteria of economy, efficiency and effectiveness.'

Alwardat et al (2015) assessed the capacity of VFM audit procedures to increase output of UK public sector organizations. The study applied the interview method for data collection and data was analyzed using descriptive statistics. The study focused on ascertaining the extent to which value for money audit improves institutional performance among government owned entities. The outcome of the study revealed that VFM audit had been poorly executed in the studied public sector entities. Furthermore, the research observed significant role conflicts the value for money process as practiced in the UK.

Adam (2014) considered the impact that efficiency, effectiveness and economy had on the Nigerian National Petroleum Corporation's (NNPC) management of Nigeria's upstream petroleum sub-sector. The focus of the study was to ascertain the extent to which NNPC ensures VFM in its utilization of Nigeria's oil assets. Findings from the study showed that NNPC has been less than efficient in its principal mandate of managing Nigeria's oil resources. This has been attributed to deficiencies in its administrative and governance structures which fostered a culture of opaque reporting and poor accountability. The study recommended that establishment of a standardized performance/benchmarking framework is an essential requirement for ensuring value addition, value for money and accountability in Nigeria's oil and gas operations.

Pollitt (2003) examined the on-going practices of value for money audit as it relates to the five Supreme Audit Institutions of Finland, France, The Netherlands, Sweden and the UK. The aim of the researcher was to articulate and clarify the key strategic choices faced by the Supreme Audit Institutions with respect to the value for money audit role. The research revealed that VFM audit as an activity is no more a mere compliance function but one that has now adopted more broadly other aspects of public sector modifications.

Bosire and Karanja (2013) investigated the impact of adequate staff training on the effectiveness or otherwise of the adoption of VFM audit in some selected local councils in Kenya. The study revealed that knowledge deficit and corruption induced maladies negatively impaired the effectiveness of VFM audit in Kenya.

Radcliff (1999) investigated the adoption of efficiency auditing as a proxy of VFM audit using some selected public institutions in Alberta, Canada. The research found that there was a dearth 


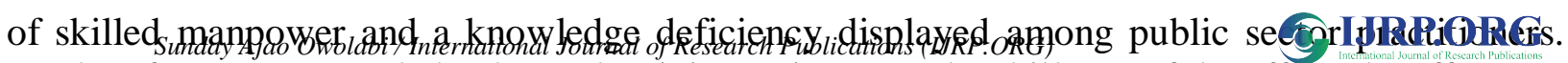

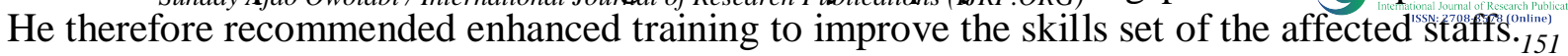

Okech (2017) evaluated the practice of VFM in the delivery of services by public sector institutions in Uganda. The research was conducted through the use of self-administered questionnaire and data obtained analyzed using descriptive data tools. The study found that public institutions did not imbibe economy in the allocation of funds which negatively impacted on the quality of service delivery.

\subsection{Methodology}

The research methodology adopted for this work was descriptive design anchored on content analysis of previous work done. Secondary sources of data used for the work was sourced from international journals written by scholars and experts, pronouncements made by professional bodies covering the fields of auditing and public finance and from other allied internet sources.

\subsection{Discussion of Findings}

This research paper emphasizes the need for public sector practitioners to embrace the need for value for money audit in their activities both from the regulatory perspectives as well as the moral burden placed on it by the society. The notion of value for money is yet to feature prominently in the configuration, arrangement and delivery of public services of developing economies even though the reverse is the case with the developing world (Lapsley and Pong 2012). This widening gap is likely to continue unless drastic measures are taken. This situation is not helped by the poor state of recruitment, training and deployment of public sector audit personnel (Alwardat and Basheik 2017). In addition, a review of existing literature particularly from the perspectives of the developing economies' showed that there is haphazard adherence to financial reporting framework governing the administration of public finance and there is scant appreciation of the impact of the elements of value for money in ensuring effective utilization of public resources. Furthermore, role conflicts and sometimes work duplications have been observed thus limiting the effectiveness of the use of value for money audit methodologies to advance the cause of probity and accountability. Consequently and in view of these myriad of challenges, the paper presented relevant practical groundwork on how value for money audit can be carried out using its embedded three elements in order to attain the desired result of proper stewardship of public resources.

The study has therefore contributed to existing body of work on the significance of value for money audit in improving transparency and probity in the management of public sector finances in Nigeria. Specifically, the study has enhanced the understanding of the impact of value for money audit by highlighting some of the major debilitating factors inhibiting optimum performance such that if properly taken care of will enhance overall productivity.

\subsection{Conclusion and Recommendations}

In Nigeria and other similar developing countries, 'value for money audit' methodologies are yet to be fully embraced in the public sector. The focal point of this study therefore was to examine the subject of value for money audits as a vital public sector engagement activity in Nigeria. Public sector engagements are multi-dimensional and multi-faceted with the desired end result been the reinforcement of probity and the conveyance of optimal service delivery. In depth review of the scores of previous works indicated that VFM audit has emerged as a vital tool for facilitating public accountability and transparency. This is especially so as the costs of governance keep escalating in developing economies while the quality of public welfare for such 


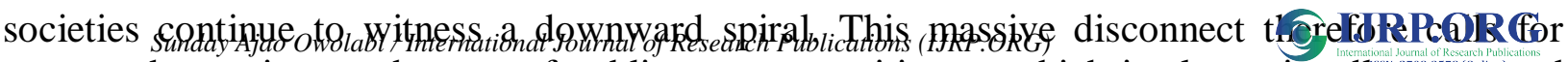
concerted attention on the part of public sector practitioners which is also pointedly expressed from the array of related literature reviewed.

This study therefore concludes that if value for money audit is properly carried out as enunciated in this work, then it can significantly aid government in reducing the costs of governance, redirecting scarce public resources to priority areas and restore public confidence in the management of national economies. The study also recommends that intensive reorientation of public sector personnel should be carried out while strict adherence to financial reporting frameworks should be encouraged. Furthermore, public sector practitioners at all levels inclusive of political leadership should display the needed will to ensure that value for money audit is given its proper place in the management of public finance.

\section{References}

Adam, I. S. (2014). An empirical investigation of the efficiency, effectiveness and economy of the nigerian national petroleum corporation's management of Nigeria's upstream petroleum sector. Robert Gordon University. PhD Thesis.

Agle, B.R., Mitchell, R. K., \&Sonnenfeld, J.A. (1999). Who matters to CEOs? An investigation of stakeholder attributes and salience, corporate performance and CEO Values. Academy of Management Journal, 42(5), 1-12

Alwardat, Y.A., Benamraoui, A., \&Rieple, A. (2015). Value for Money and Audit Practice in the UK Public Sector. International Journal of Auditing, 19(3), 206-217

Blattberg, C., (2013). Welfare: Towards the patriotic corporation. SSRN Electronic Journal DOI: $10.2139 /$ ssrn. 2250348

Bloomfield, D., Collins, K., Fry, C. \& Munton, R., (2001): Deliberation and inclusion: vehicles for increasing trust in UK public governance. Government and Policy Journal. 19(1):501-513

Burchell, K. (2015) Factors affecting public engagement by researchers: literature review. Policy Studies Institute, London

Changalima, I. A. (2016). Determinants of value for money in the procurement of works in public sector: a survey of selected government ministries in Dar es Salaam in Tanzania. A Dissertation submitted to Mzumbe University.

Chew, H.,Suhaiza, I., \&Fatima, A. H. (2016). The perception of public sector auditors on performance audit in Malaysia: An exploratory study

Domas-Hantke, M. (2003). The public interest theory of regulation: non-existence or misinterpretation? European Journal of Law and Economics, 15(2), 165-194

Eze, N.M.,\& Ibrahim, M. M. (2015) Value for money audit: a veritable tool for expenditure management. International Journal of Financial Research, 6(3), 1-13

Flesher, D.L \&Zarzeski, M. T. (2002). The roots of operational (value-for-money) auditing in English-speaking nations. Accounting and Business Research, 32(2), 93-104 


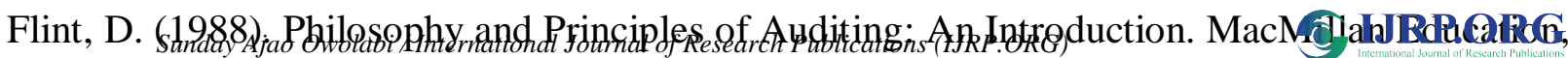
London

Freeman, R. (1984). The politics of stakeholder theory: Some future directions. Business Ethics Quarterly, 4(4), 409-421.

Grossman S.J.,(1981). An Introduction to the Theory of Rational Expectations Under Assymentric Information. The Review of Economic Information. The Review of Economic Studies Journal. 48(4):541-559

Hayes, R.S., Schilder, A., Dassen, R. and Wallage, P. (1999) Principles of Auditing: An International Perspective. McGraw-Hill Publishing Company, London

Hertog R., (2010) Review of economic theories of regulation. Tjalling C. Koopmans Research Institute, Netherlands, Discussion Paper 10-18

Idada W., and Ihunmwuangbo S.O(2012). Problems of Democratic Governance in Nigeria: The Way Forward. Journal of Sociology and Social Anthropology.3 (1):49-54

IIA (2012) Supplemental Guidance: The role of auditing in public sector governance. $\left(2^{\text {nd }}\right.$ Edition)

INTOSAI (1992), ‘Auditing Standards’ Auditing Standards Committee

Lapsley I.,\& Pong C.K.,(2012). Modernization versus problematization: value-for-money audit in public services. European Accounting Review Journal. 9(4):541-567

Lewis A.(1949). The Principles of Economic Planning. George Allen and Unwind. London

Limperg, T. (1932). Theory of inspired confidence. University of Amsterdam: Netherlands.

Mahbuba, K.M., (2012). Impact of value for money audit on government social programmes: a study of forest management in bangladesh with particular focus in social forestry. An MSc Dissertation Submitted to Department of General and Continuing Education North South University.

Mautz R.K, Sharaf H.A.,(1961). The philosophy of auditing. american association of accounting. Florida

Maria Katsonis (2019) Designing effective public engagement: the case study of Future Melbourne 2026, Policy Design and Practice, 2(2):215-228

McSweeney B., Sherer M. (1990) Value for money auditing: Some observations on its origins and theory in: Cooper D.J., Hopper T.M. (eds) Critical A/cs. Palgrave, London

Munian, A.Y. (2005)Value for money audits and e-government: Benchmarking best practices. Public Performance \& Management Review, 29(2), 111-124

Mhilu, F.M.H. (2002). Advanced auditing and investigation, a comprehensive manual for professionals, NBAA-Tanzania 


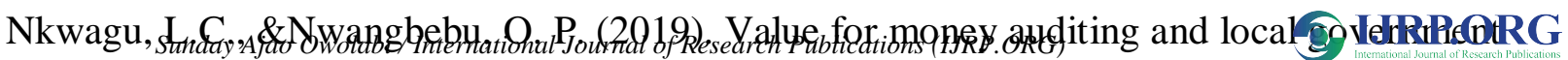
service delivery in ebonyi state: a study of selected local government areas., Acade Accounting and Financial Studies Journal, 23(5), 1-21

Nirmala, N., Van Peursem, K., \& Lowe, A. (2006) Emergence of public sector performance auditing: A historical perspective. Malaysian Accounting review, 5(1), 43-51

Nwangbebu, O.P., Oketa, C.E., Agba, C.C., Nwambe, C. O. (2019). Effect of value for money auditing on cost of governance in Nigeria: Evidence from local government councils in Ebonyi State, Nigeria. International Journal of Academic Research in Accounting, Finance and Management Sciences.,9(1), 170-178

NIAO. (2006).Northern Ireland auditing office (NIAO) 2006 annual report OAG (2012),office of the auditor general Canada 2012-2013 Annual Report

Okech B.B.,(2017). Value of Money in the Provision of Services in the Public Sector in Uganda Texila International Journal of Management. 3(2):320-336

Okwoli, A.A., (2004). Value for money auditing in the Nigerian public sector: Its problems and Prospects in the Next Millennium. Go-go Intl Ltd. Jos

Ogoun, S. and Odogu, T.K.Z. (2020) The Adequacy of the Auditor's Report in the Anti-Graft Age: A Forensic View. iBusiness, 12 13-32.

Organisation for Economic Co-operation and Development. (2009). Focus on Citizens: Public Engagement for Better Policy and Services. Paris: OECD Publishing

Oshisami. K., (2004) Government Accounting and Financial Control. Pitman, Lagos

Owolabi S.A, Jaiyeoba O.O., \& Ajibade A.T., (2016). Development and Evolution of Auditing. Unique Journal of Business Management Research.3 (1):32-40

Peters G. T., \& Bagshaw, K. O. (2014) Corporate governance mechanisms and Financial performance of listed firms in Nigeria: a content analysis. Global Journal of Contemporary Research in Accounting, Auditing, and Business Ethics, 1(2), 103-128

Pigou, A. C. (1932). The economics of welfare. London, Macmillan and Co.

Pollitt, C. (2003).The essential public manager, McGraw-Hill Education (UK) Publishing.

Radcliff (1999) Operationalization of efficiency auditing through the analysis of the VFM audits in Alberta, Canada.

Santos, J. B., \&Brito, L.A. (2012). Towards a subjective measurement model for firm performance. Brazilian Administration Review, 9, 95-117.

Shleifer A.(2005). Understanding Regulation. European Financial Management Journal.11 (4):439-451

Smyth, R., Söderberg, M.(2010). Public interest versus regulatory capture in the Swedish electricity market. Journal of Regulatory Economics, 38 (3), 292-312 
Sombart, W.,(1953). Medieval and Modern Commercial Enterprise, Enterprise and Sececularar 155 Change. 25-40

Tan, K. P.,(2012). Public Engagement: The Gap between Rhetoric and Practice. Civil Service College of Singapore Publication.

Tanko M.,Samuel, G., \&Dabo, Z. (2010). Value for money audit in Nigerian local government area councils: An empirical examination. Proceedings' of the Northeast Business and Economics, 8, 113-116

TonadeA.M \& Adesanwo O.E, (2017) Audit Principles and Practical Guidelines. Ago-Iwoye, Ogun State, U-Phemison\& Co. Limited

Udeh, S.,\&Elom J.(2016). Challenges of performance auditing in public sector accountability in Nigeria: A study of the Office of Auditor General. ESUT Journal of Accountancy, 7(1), 1-13. 